\title{
Exploring metallodrug-protein interactions by mass spectrometry: comparisons between platinum coordination complexes and an organometallic ruthenium compound
}

\author{
Angela Casini - Chiara Gabbiani - Elena Michelucci · \\ Giuseppe Pieraccini · Gloriano Moneti • \\ Paul J. Dyson · Luigi Messori
}

Received: 15 December 2008/Accepted: 20 February 2009/Published online: 14 March 2009 (C) SBIC 2009

\begin{abstract}
Electrospray ionisation mass spectrometry was used to analyse the reactions of metal compounds with mixtures of selected proteins. Three representative medicinally relevant compounds, cisplatin, transplatin and the organometallic ruthenium compound RAPTA-C, were reacted with a pool of three proteins, ubiquitin, cytochrome $c$ and superoxide dismutase, and the reaction products were analysed using high-resolution mass spectrometry. Highly informative electrospray ionisation mass spectra were acquired following careful optimisation of the experimental conditions. The formation of metal-protein adducts was clearly observed for the three proteins. In addition, valuable information was obtained on the nature of the proteinbound metallofragments, on their distribution among the three different proteins and on the binding kinetics. The platinum compounds were less reactive and considerably
\end{abstract}

Electronic supplementary material The online version of this article (doi:10.1007/s00775-009-0489-5) contains supplementary material, which is available to authorized users.

A. Casini $(\varangle) \cdot$ P. J. Dyson

Institut des Sciences et Ingénierie Chimiques,

Ecole Polytechnique Fédérale de Lausanne (EPFL),

1015 Lausanne, Switzerland

e-mail: angela.casini@epfl.ch

C. Gabbiani · L. Messori

Department of Chemistry,

University of Florence,

Via della Lastruccia 3,

50019 Sesto Fiorentino, Italy

E. Michelucci · G. Pieraccini - G. Moneti

Mass Spectrometry Centre (CISM),

University of Florence,

Via U. Schiff 6 ,

50019 Sesto Fiorentino, Italy less selective in protein binding than RAPTA-C, which showed a high affinity towards ubiquitin and cytochrome $c$, but not superoxide dismutase. In addition, competition studies between cisplatin and RAPTA-C showed that the two metallodrugs have affinities for the same amino acid residues on protein binding.

Keywords Cisplatin - Metal-based drugs - Proteins . Bioorganometallic chemistry $\cdot$ Mechanism of action

\section{Introduction}

Platinum-based compounds are widely used in the treatment of cancer [1]. However, in recent years a vast number of non-platinum compounds has been prepared and evaluated as experimental anticancer drugs [2-6]. Among them, ruthenium(II)-arene complexes bearing 1,3,5-triaza7-phosphaadamantane (pta) ligands-named 'RAPTA' [7] — have been found to exhibit promising antimetastatic properties in vivo, and appear to function in a way different from cisplatin. [8-10] Indeed, ruthenium complexes could prove to be effective alternatives to those based on platinum, and trans-[tetrachloro(dimethyl sulphoxide)(imidazole) ruthenate(III)] (NAMI-A) [11] and trans-[tetrachlorobis (1H-indazole)ruthenate(III)] (KP1019) [12] have both completed phase I clinical trials.

Since DNA is considered as the primary target for platinum metallodrugs [13, 14], interest in the field has mainly focused on the characterisation of metal complexnucleic acid adducts, with considerably less attention being paid to other potential biomolecular targets. However, the mechanisms of action of ruthenium-based anticancer compounds are comparatively unexplored, although it is clear that ruthenium compounds interact far more weakly 
with DNA relative to platinum compounds [15]. There is evidence to suggest that ruthenium compounds might directly interfere with specific proteins involved in signal transduction pathways and/or alter cell adhesion and migration processes $[10,16,17]$.

Within this frame, it is of particular interest to develop specific methods to analyse the reactivity of metallodrugs towards potential cellular targets, in particular proteins and enzymes. Moreover, protein-bound metallofragments potentially represent the actual active anticancer species present in vivo - rather than simple drug activation products-provided that transfer of the metal among specific binding sites is kinetically favoured [18]. In addition, metallation of specific amino acid residues, affecting the function of biologically crucial proteins through the formation of strong coordination (covalent) bonds, might play a relevant role in the overall toxicological profile of metalbased drugs [19-21]. Indeed, a number of reviews on metallodrug-protein interactions have been published that explore various aspects of their relevance to anticancer activity [22-24].

In recent years, electrospray ionisation (ESI) mass spectrometry (MS) has emerged as an extremely valuable and powerful method to monitor the formation of protein adducts of classic and new-generation metallodrugs, even allowing the binding site of the resulting metallic fragment(s) to be ascertained [25, 26]. However, the optimisation and the standardisation of experimental ESI MS procedures directed to metallodrugs require attention, since the variability in the ESI MS response depends on many factors, such as the nature of the protein, the nature of the metal/ligands/charge and the specific solution conditions (pH, buffer, etc.) [27, 28].

The reactivity of several metal anticancer compounds with model proteins such as cytochrome $c$ or ubiquitin has been studied using ESI MS [29-32]. Combined, these studies show that ESI MS allows rapid and unambiguous identification of the nature of protein-bound metal-containing molecular fragments. However, the studies undertaken to date do not provide direct information on the actual selectivity of the metal compound towards a certain protein in the presence of other proteins, or provide any information on compound selectivity with respect to protein binding. Accordingly, herein we describe a novel highresolution ESI MS approach to study the reactions of metal complexes [cisplatin, transplatin and an arene-capped ruthenium(II) compound $\mathrm{Ru}\left(\eta^{6}-p\right.$-cymene)(pta) $\mathrm{Cl}_{2}$, RAPTA-C; Fig. 1] with a mixture of three different model proteins (cytochrome $c$, ubiquitin and superoxide dismutase, SOD). In addition, competitive binding of a mixture of cisplatin and RAPTA-C with the protein mixture was studied, providing insights into their preferred binding sites. As far as we are aware, this is the first time that such
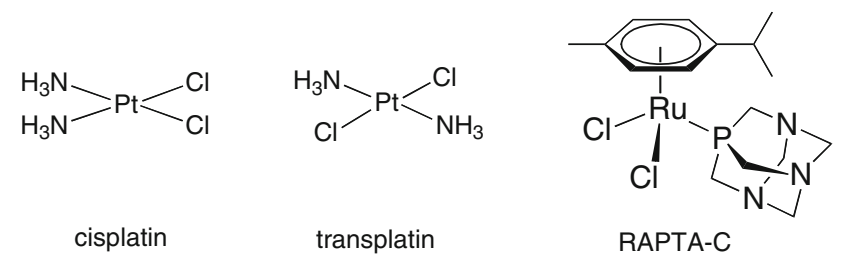

Fig. 1 Structures of the metal complexes employed in this study

approaches involving protein mixtures have been used to study metal-based drugs.

It is worth mentioning that while the proteins were selected as a model system for evaluation/optimisation of the approach, they each have important functions relevant to cancer. Cytochrome $c$ is an important protein crucially involved in apoptotic pathways [33], ubiquitin is relevant in posttranslational modification of proteins together with the proteasome system [34] and SOD is relevant to human diseases by catalysing the conversion of single-electronreduced species of molecular oxygen to hydrogen peroxide and oxygen [35]. Of particular relevance to this study, these proteins have characteristics that make them suitable for MS analysis; they are of small to moderate size, with molecular mass ranging from 6,500 to 15,000 Da (SOD in the monomeric form). Moreover, they are commercially available, manifest a high stability in solution under physiological-type conditions and are water-soluble. In most cases, they are easy ionisable and optimal for ESI MS detection in positive ion mode. In addition, for all these proteins high-resolution crystal structures or NMR structural data are available that complement the identification of the probable metal binding sites (e.g. the most-surfaceexposed residues).

\section{Materials and methods}

\section{Metal complexes and proteins}

Horse heart cytochrome $c$, red blood cell ubiquitin and bovine erythrocyte SOD were purchased from Sigma (C7752, U6253 and S2515, respectively) and used as received. Cisplatin and transplatin were obtained from Sigma and RAPTA-C was prepared using a literature method [4].

Sample preparation and mass-spectrometric analysis

Samples were prepared by mixing equivalent amounts of the three proteins $(100 \mu \mathrm{M})$ in $25 \mathrm{mM}$ tetramethylammonium acetate buffer ( $\mathrm{pH} 7.4)$. Then each of the selected metal complexes was added to the solutions (5:1 metal-toprotein ratio) and incubated at $37^{\circ} \mathrm{C}$ for different time 


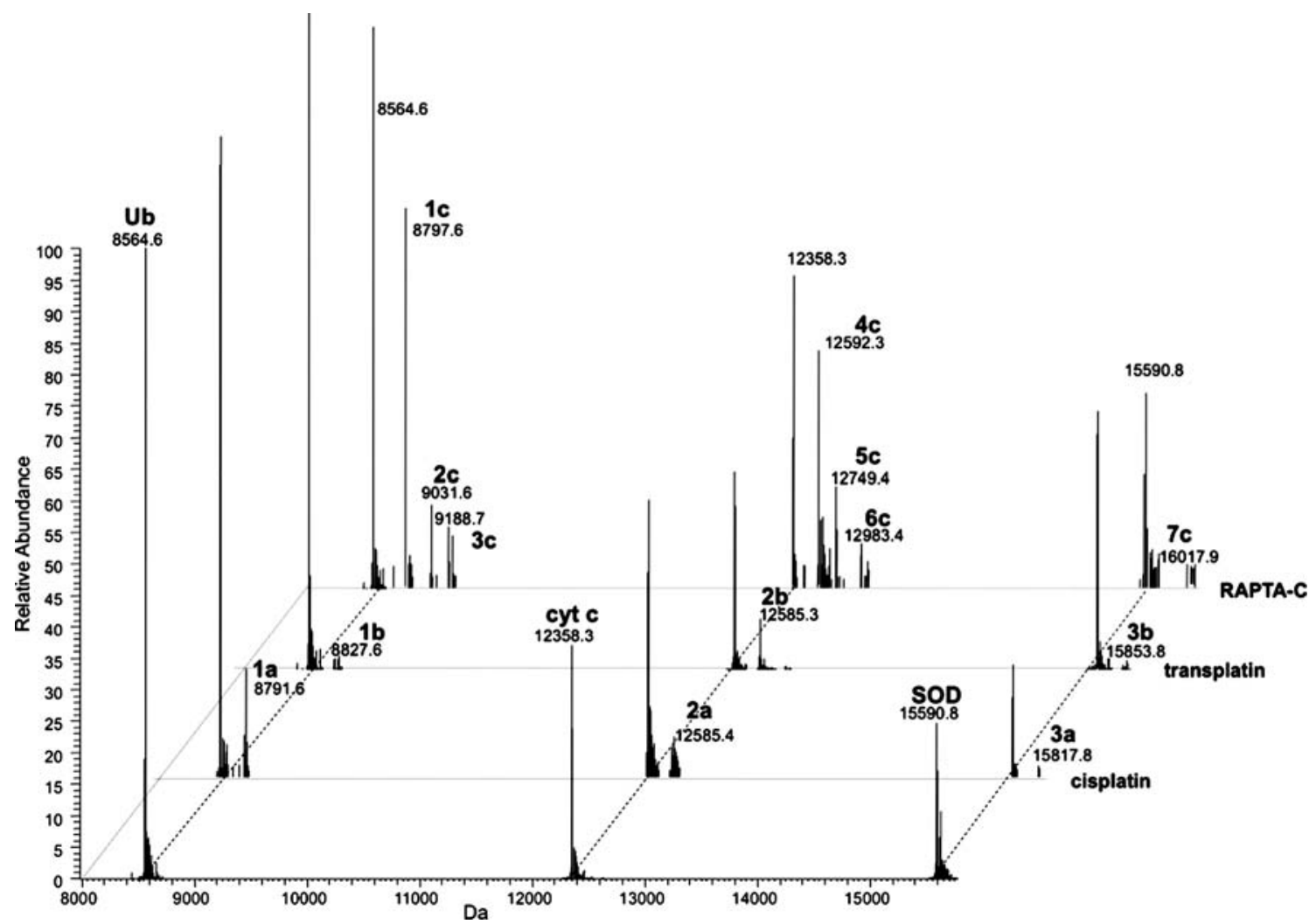

Fig. 2 LTQ-Orbitrap electrospray ionisation (ESI) mass spectra of a mixture of ubiquitin $(U b)$, cytochrome $c(c y t c)$ and superoxide dismutase $(S O D)(1: 1: 1)$ in tetramethylammonium acetate (TMeAmAc) buffer $\mathrm{pH} 7.4$ and the same protein mixture after 24-h incubation at $37^{\circ} \mathrm{C}$ with cisplatin, transplatin and RAPTA-C, respectively (5:1 metal-to-protein ratio). Peaks corresponding to the main adducts have been assigned as follows: $1 a \mathrm{Ub}-\mathrm{Pt}\left(\mathrm{NH}_{3}\right)_{2} ; 2 a$ cyt

intervals. Prior to analysis, samples were extensively ultrafiltered using a Centricon YM-3 filter (Amicon Bioseparations, Millipore Corporation) to remove the unbound complex. For the competition experiments, proteins samples containing both cisplatin and RAPTA-C (5:1 metalto-protein ratio) were prepared as described above and analysed by MS over a period of $48 \mathrm{~h}$. In a second type of competition experiment, proteins samples containing either cisplatin or RAPTA-C (5:1 metal-to-protein ratio) were prepared as previously described and incubated for $72 \mathrm{~h}$ at $37{ }^{\circ} \mathrm{C}$. Then an excess (5:1 metal-to-protein ratio) of the second metal complex (RAPTA-C or cisplatin) was added and the incubation was continued for another $24 \mathrm{~h}$. Each sample was analysed in triplicate.

After a 20-fold dilution with $\mathrm{HCOOH}(0.1 \%)$, ESI MS spectra were recorded by direct introduction at a $3 \mu \mathrm{L} / \mathrm{min}$ flow rate into an LTQ-Orbitrap high-resolution mass spectrometer (Thermo, San Jose, CA, USA), equipped with a conventional ESI source. The working conditions comprised the following: spray voltage $3.1 \mathrm{kV}$, capillary voltage $45 \mathrm{~V}$ and capillary temperature $220^{\circ} \mathrm{C}$. The sheath
$c-\mathrm{Pt}\left(\mathrm{NH}_{3}\right)_{2} ; 3 a$ SOD-Pt $\left(\mathrm{NH}_{3}\right)_{2} ; \quad 1 b$ Ub- $\left[\mathrm{Pt}\left(\mathrm{NH}_{3}\right) \mathrm{Cl}\right] ; 2 b$ cyt $c-$ $\mathrm{Pt}\left(\mathrm{NH}_{3}\right)_{2} ; 3 b \quad \mathrm{SOD}-\left[\mathrm{Pt}\left(\mathrm{NH}_{3}\right) \mathrm{Cl}\right] ; \quad 1 c \quad \mathrm{Ub}-\left[\mathrm{Ru}\left(\eta^{6}-p\right.\right.$-cymene $\left.)\right] ; 2 c$ $\mathrm{Ub}+2\left[\mathrm{Ru}\left(\eta^{6}-p\right.\right.$-cymene $\left.)\right] ; \quad 3 c \quad \mathrm{Ub}-\left[\mathrm{Ru}\left(\eta^{6}-p\right.\right.$-cymene $\left.)(\mathrm{pta})\right]+\mathrm{Ub}-$ $\left[\mathrm{Ru}\left(\eta^{6}-p\right.\right.$-cymene $\left.)\right] ; 4 c$ cyt $c-\left[\mathrm{Ru}\left(\eta^{6}-p\right.\right.$-cymene $\left.)\right] ; 5 c$ cyt $c-[\mathrm{Ru}$ $\left(\eta^{6}-p\right.$-cymene $\left.)(\mathrm{pta})\right] ; 6 c$ cyt $c-\left[\mathrm{Ru}\left(\eta^{6}-p\right.\right.$-cymene $\left.)(\mathrm{pta})\right]+$ cyt $c-[\mathrm{Ru}$ $\left(\eta^{6}-p\right.$-cymene $\left.)\right] ; 7 c$ SOD-[Ru( $\eta^{6}-p$-cymene $\left.)(\mathrm{pta}) \mathrm{Cl}\right] . \mathrm{pta}$ is $1,3,5-$ triaza-7-phosphaadamantane

and the auxiliary gases were set, respectively, at 17 (arbitrary units) and 1 (arbitrary unit). For acquisition, Xcalibur 2.0 software (Thermo) was used and monoisotopic and average deconvoluted masses were obtained by using the integrated Xtract tool. For spectra acquisition, a nominal resolution (at $\mathrm{m} / \mathrm{z}, 400)$ of 100,000 was used.

\section{Results and discussion}

High-resolution LTQ-Orbitrap ESI MS [36] was used to monitor the adducts formed between cisplatin, transplatin and the organometallic compound RAPTA-C with a mixture of three proteins in solution (cytochrome $c$, ubiquitin and SOD). High-resolution ESI MS has previously been used to study covalent and non-covalent ligand-biomolecule interactions $[37,38]$ and to screen complex mixtures of metabolites [39-41], often without the need for chromatographic separation of the adducts prior to analysis. Hence, this method allows the simultaneous screening of complicated mixtures of compounds with the direct 
Table 1 Main peaks identified in the deconvoluted mass spectra of cisplatin-, transplatin- and $\mathrm{Ru}\left(\eta^{6}-p\right.$-cymene $)(\mathrm{pta}) \mathrm{Cl}_{2}$ (RAPTA-C)treated protein mixtures after 24 -h incubation at $37{ }^{\circ} \mathrm{C}$

\begin{tabular}{|c|c|c|}
\hline Compound & Mass (Da) & Protein-metal adduct \\
\hline \multirow[t]{5}{*}{ Cisplatin } & $8,774.6$ & $\mathrm{Ub}-\mathrm{Pt}\left(\mathrm{NH}_{3}\right)$ \\
\hline & $8,791.6$ & $\mathrm{Ub}-\mathrm{Pt}\left(\mathrm{NH}_{3}\right)_{2}$ \\
\hline & $12,569.3$ & Cyt $c-\mathrm{Pt}\left(\mathrm{NH}_{3}\right)$ \\
\hline & $12,585.4$ & Cyt $c-\mathrm{Pt}\left(\mathrm{NH}_{3}\right)_{2}$ \\
\hline & $15,817.8$ & $\mathrm{SOD}-\mathrm{Pt}\left(\mathrm{NH}_{3}\right)_{2}$ \\
\hline \multirow[t]{6}{*}{ Transplatin } & $8,791.6$ & $\mathrm{Ub}-\mathrm{Pt}\left(\mathrm{NH}_{3}\right)_{2}$ \\
\hline & $8,827.6$ & $\mathrm{Ub}-\left[\mathrm{Pt}\left(\mathrm{NH}_{3}\right)_{2} \mathrm{Cl}\right]$ \\
\hline & $12,585.3$ & Cyt $c-\mathrm{Pt}\left(\mathrm{NH}_{3}\right)_{2}$ \\
\hline & $12,622.3$ & Cyt $c-\left[\mathrm{Pt}\left(\mathrm{NH}_{3}\right)_{2} \mathrm{Cl}\right]$ \\
\hline & $15,817.8$ & $\mathrm{SOD}-\mathrm{Pt}\left(\mathrm{NH}_{3}\right)_{2}$ \\
\hline & $15,853.8$ & $\mathrm{SOD}-\left[\mathrm{Pt}\left(\mathrm{NH}_{3}\right)_{2} \mathrm{Cl}\right]$ \\
\hline \multirow[t]{9}{*}{ RAPTA-C } & $8,797.6$ & $\mathrm{Ub}-\left[\mathrm{Ru}\left(\eta^{6}-p\right.\right.$-cymene $\left.)\right]$ \\
\hline & $9,031.6$ & $\mathrm{Ub}+2\left[\mathrm{Ru}\left(\eta^{6}-p\right.\right.$-cymene $\left.)\right]$ \\
\hline & $9,188.7$ & $\begin{array}{l}\mathrm{Ub}-\left[\mathrm{Ru}\left(\eta^{6}-p \text {-cymene }\right)(\mathrm{pta})\right] \\
\quad+\mathrm{Ub}-\left[\mathrm{Ru}\left(\eta^{6}-p \text {-cymene }\right)\right]\end{array}$ \\
\hline & $9,223.7$ & $\begin{array}{l}\mathrm{Ub}-\left[\mathrm{Ru}\left(\eta^{6}-p \text {-cymene }\right)(\mathrm{pta}) \mathrm{Cl}\right] \\
\quad+\mathrm{Ub}-\left[\mathrm{Ru}\left(\eta^{6}-p \text {-cymene }\right)\right]\end{array}$ \\
\hline & $12,592.3$ & Cyt $c-\left[\operatorname{Ru}\left(\eta^{6}-p\right.\right.$-cymene $\left.)\right]$ \\
\hline & $12,749.4$ & Cyt $c-\left[\mathrm{Ru}\left(\eta^{6}-p\right.\right.$-cymene $\left.)(\mathrm{pta})\right]$ \\
\hline & $12,983.4$ & $\begin{array}{r}\text { Cyt } c-\left[\operatorname{Ru}\left(\eta^{6}-p \text {-cymene }\right)(\mathrm{pta})\right] \\
+ \text { cyt } c-\left[\operatorname{Ru}\left(\eta^{6}-p \text {-cymene }\right)\right]\end{array}$ \\
\hline & $15,822.8$ & $\operatorname{SOD}-\left[\operatorname{Ru}\left(\eta^{6}-p\right.\right.$-cymene $\left.)\right]$ \\
\hline & $16,017.9$ & $\mathrm{SOD}-\left[\mathrm{Ru}\left(\eta^{6}-p\right.\right.$-cymene $\left.)(\mathrm{pta}) \mathrm{Cl}\right]$ \\
\hline
\end{tabular}

Ub ubiquitin, cyt $c$ cytochrome $c, S O D$ superoxide dismutase, pta 1,3,5-triaza-7-phosphaadamantane

identification of the reaction products, i.e. metallodrugprotein adducts. Although ESI MS is not a quantitative technique, it can be used to screen multicomponent systems, providing a semiquantitative description of the abundance of the species in solution [42]. Typically, ESI MS has been applied to establish the affinity of multiple potential ligands for a single macromolecular target; however, related procedures have been used to study ligand binding to (and affinity for) a protein mixture [38]. Moreover, Will et al. [43, 44] have recently demonstrated the suitability of an automated method for shotgun proteomics based on ESI MS for establishing some of the protein targets of transition metal complexes in whole-cell systems.

Deconvoluted mass spectra of the mixture of the three proteins incubated with each of the selected compounds (5:1 metal-to-protein ratio) in aqueous solution at $\mathrm{pH} 7.4$, for $24 \mathrm{~h}$ at $37^{\circ} \mathrm{C}$, are shown in Fig. 2 together with a spectrum of the untreated protein mixture for comparison purposes. A list of the main peaks is given in Table 1 . The untreated protein sample (Fig. 2) shows three wellseparated peaks at $8,564.6,12,358.3$ and $15,590.8 \mathrm{Da}$ corresponding to the molecular masses of ubiquitin, cytochrome $c$ and SOD, respectively.

The deconvoluted mass spectrum of the proteins incubated with cisplatin (Fig. 2) shows numerous additional peaks. A series of peaks centred at 8,791.6 Da corresponds to platinum monoadducts, the most intense one $(15-20 \%$ relative intensity) in which a single $\left[\mathrm{Pt}\left(\mathrm{NH}_{3}\right)_{2}\right]^{2+}$ fragment is coordinated to ubiquitin (see Table 1 for all peak assignments). A similar pattern is found in the case of cytochrome $c$ and SOD adducts, in which peaks at $12,585.4 \mathrm{Da}$ (15-20\% relative intensity) and at 15,817.8 $\mathrm{Da}$ (15-20\% relative intensity) correspond to the proteins with a single $\left[\mathrm{Pt}\left(\mathrm{NH}_{3}\right)_{2}\right]^{2+}$ fragment bound. A $\left[\mathrm{Pt}\left(\mathrm{NH}_{3}\right)\right]^{2+}$ fragment attached to ubiquitin and cytochrome $c$ is also observed (see Table 1), albeit with low relative intensity (5-10\% relative intensity), in which an ammonia ligand has been lost. These data match well with those from previous studies of cisplatin binding to single proteins [22, 26, 27]. All of the monoplatinated protein species are of approximately equal relative intensity (totalling around 10-20\% relative intensity) with respect to the free protein signals, demonstrating that cisplatin reacts with each protein in the mixture to a similar extent.

The reactivity of transplatin with the mixture of proteins was also evaluated to establish the differences in reactivity between cisplatin and its inactive isomer. Overall, the behaviour of transplatin is very similar to that of cisplatin (Fig. 2, Table 1), with the $\left[\mathrm{Pt}\left(\mathrm{NH}_{3}\right)_{2}\right]^{2+}$ fragment being the most common species formed. However, for transplatin, loss of ammonia is not observed since it is not labilised by a trans effect on protein binding. Instead, peaks corresponding to species containing $\left[\mathrm{Pt}\left(\mathrm{NH}_{3}\right)_{2} \mathrm{Cl}\right]^{+}$fragments are observed. In contrast to cisplatin, a slight preference for cytochrome $c$ binding can be inferred from the relative intensities of the adducts relative to the free proteins (25$30 \%$ relative intensity for the cytochrome $c$ adducts compared to only $5-10 \%$ relative intensity for the adducts with ubiquitin and SOD).

The spectrum of the proteins incubated with RAPTA-C (Fig. 2) shows marked differences with respect to the spectrum of protein mixture incubated with the platinum compounds. Overall, a considerably higher reactivity of RAPTA-C is observed, with the most abundant adduct peaks being obtained with ubiquitin and cytochrome $c$ (approximately $70-80 \%$ relative intensity). In fact, after $24 \mathrm{~h}$ both monoruthenium and bisruthenium adducts are formed with ubiquitin and cytochrome $c$ (Table 1). In all cases, peaks corresponding to $\left[\left(\eta^{6} \text {-cymene }\right) \mathrm{Ru}\right]^{2+}$ and $\left[\left(\eta^{6}-\right.\right.$ cymene)(pta)Ru $]^{2+}$ fragments are detected, but with different relative intensities, the pta-containing adduct being less intense. Notably, RAPTA-C shows a marked selectivity for cytochrome $c$ and ubiquitin binding, with adduct peaks of greater relative intensity than the peaks of the 


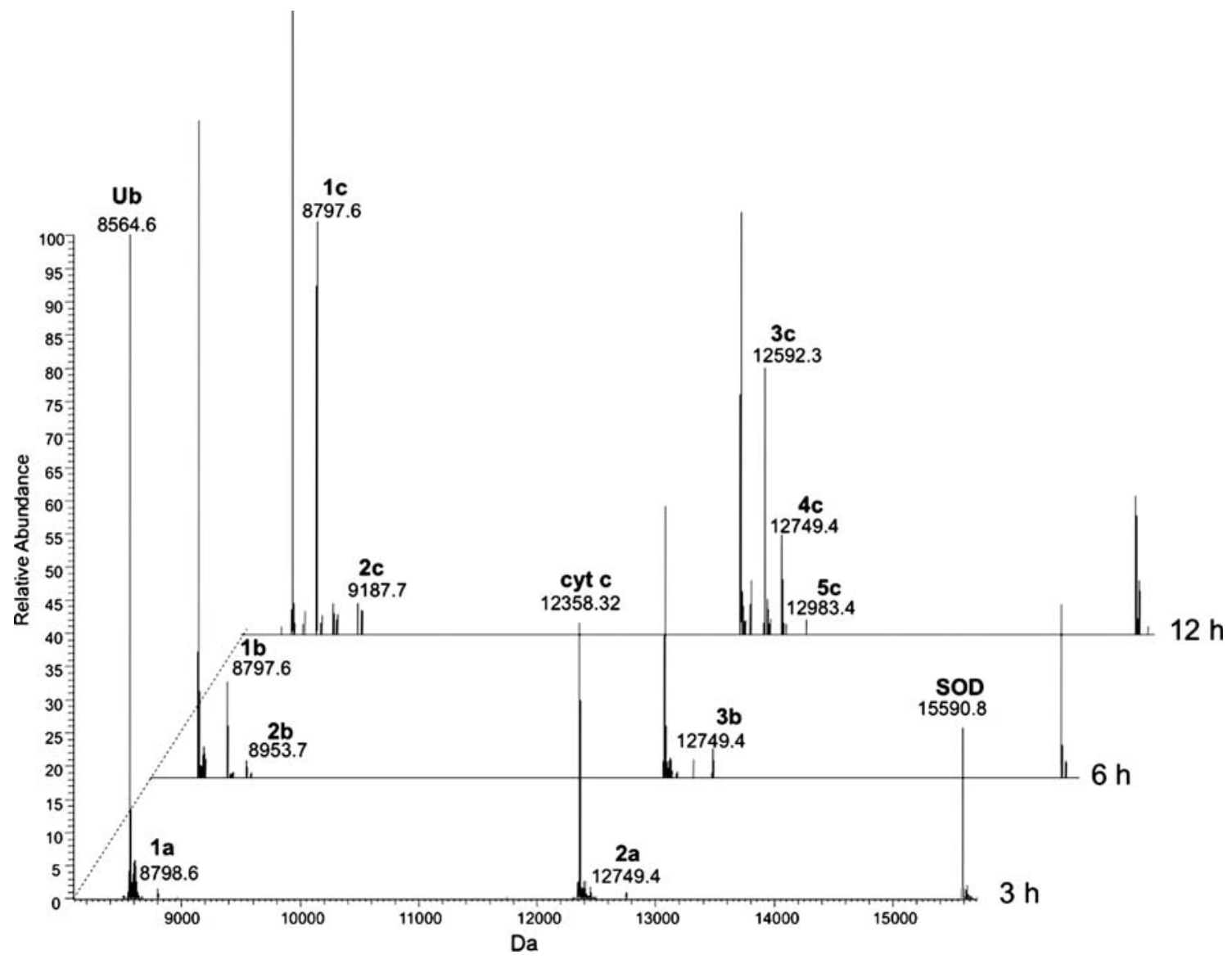

Fig. 3 Time-dependent mass-spectrometric analysis of the protein mixture treated with RAPTA-C (5:1 metal-to-protein ratio) in TMeAmAc buffer pH 7.4 and incubated for 3,6 and $12 \mathrm{~h}$ at $37{ }^{\circ} \mathrm{C}$. The mass peaks were assigned as follows: $1 a, 1 b 1 c \mathrm{Ub}-\left[\mathrm{Ru}\left(\eta^{6}-p\right.\right.$ -

unbound proteins, whereas for SOD only adducts of low relative intensity are observed (10-15\% relative intensity). These findings demonstrate that the organometallic ruthenium compound has a greater affinity towards protein binding than cisplatin (and transplatin), but also that the compound has an intrinsic selectivity towards certain proteins (see below).

Kinetic studies were performed to further characterise protein binding of RAPTA-C. Spectra of the mixture of the three proteins treated with RAPTA-C were analysed at different time intervals over a period of $24 \mathrm{~h}$ and the spectra obtained are compiled in Fig. 3, with assignments given in Table 2. After $3 \mathrm{~h}$, peaks with low relative intensities corresponding to ruthenium-bound fragments are detected. Specifically, peaks at approximately 8,798 and $12,749 \mathrm{Da}$ (5-10\% relative intensity) correspond to monoadducts of $\left[\operatorname{Ru}\left(\eta^{6}-p \text {-cymene }\right)\right]^{2+}$ and $\left[\mathrm{Ru}\left(\eta^{6}-p\right.\right.$-cymene)pta $]^{2+}$ species with ubiquitin and cytochrome $c$, respectively. It is noteworthy that the $\left[\mathrm{Ru}\left(\eta^{6}-p \text {-cymene }\right)\right]^{2+}$ fragment in which the pta and chloride ligands have been lost forms preferentially with ubiquitin, whereas with cymene)]; $2 a, 3 b, 4 c$ cyt $c-\left[\mathrm{Ru}\left(\eta^{6}-p\right.\right.$-cymene)(pta) $] ; 2 b \mathrm{Ub}-\left[\mathrm{Ru}\left(\eta^{6}-p-\right.\right.$ cymene)(pta)Cl]; $2 c \quad \mathrm{Ub}-\left[\mathrm{Ru}\left(\eta^{6}-p\right.\right.$-cymene $\left.)(\mathrm{pta})\right]+\mathrm{Ub}-\left[\mathrm{Ru}\left(\eta^{6}-p-\right.\right.$ cymene $)] ; 3 c$ cyt $c-\left[\operatorname{Ru}\left(\eta^{6}-p\right.\right.$-cymene $\left.)\right] ; 5 c$ cyt $c-\left[\operatorname{Ru}\left(\eta^{6}-p\right.\right.$-cymene)(pta) $]+$ cyt $c-\left[\operatorname{Ru}\left(\eta^{6}-p\right.\right.$-cymene $\left.)\right]$

cytochrome $c$ the only coordinated fragment is $\left[\mathrm{Ru}\left(\eta^{6}-p-\right.\right.$ cymene)pta $]^{2+}$, which retains the pta ligand. No adducts with SOD are observed at this time. After $6 \mathrm{~h}$, the spectrum contains the same series of peaks, but the relative intensities of the adduct peaks have increased relative to the peaks of the free proteins. In addition, the signal of a $\left[\mathrm{Ru}\left(\eta^{6}-p\right.\right.$ cymene) $]^{2+}$ fragment bound to cytochrome $c$ appears at approximately $12,592 \mathrm{Da}$ (10\% relative intensity). After 12-h incubation, all the signals corresponding to ruthenium adducts increase in intensity. Remarkably, a net increase of the cytochrome $c-\left[\operatorname{Ru}\left(\eta^{6}-p \text {-cymene }\right)\right]^{2+}$ adduct $(60 \%$ relative intensity) is observed. Notably, at $12 \mathrm{~h}$ no adducts with SOD are observed. After 24-h incubation, the situation is essentially the same (Fig. 2, Table 1), except minor adducts with SOD are observed.

The competitive binding of cisplatin and RAPTA-C towards the protein mixture was also studied. Samples were prepared by mixing the three proteins with an excess of cisplatin and RAPTA-C. Through this approach it was possible to establish if the two complexes compete for the same binding sites or if they target different amino acid 
Table 2 Main peaks identified in the deconvoluted mass spectra of RAPTA-C-treated protein mixtures after 3-, 6- and 12-h incubation at $37{ }^{\circ} \mathrm{C}$

\begin{tabular}{|c|c|c|}
\hline Time (h) & Mass (Da) & Protein/RAPTA-C adduct \\
\hline \multirow[t]{3}{*}{3} & $8,798.6$ & $\mathrm{Ub}-\left[\mathrm{Ru}\left(\eta^{6}-p\right.\right.$-cymene $\left.)\right]$ \\
\hline & $8,953.7$ & $\mathrm{Ub}-\left[\mathrm{Ru}\left(\eta^{6}-p\right.\right.$-cymene $\left.)(\mathrm{pta})\right]$ \\
\hline & $12,749.4$ & Cyt $c-\left[\operatorname{Ru}\left(\eta^{6}-p\right.\right.$-cymene $\left.)(\mathrm{pta})\right]$ \\
\hline \multirow[t]{4}{*}{6} & $8,797.6$ & $\mathrm{Ub}-\left[\mathrm{Ru}\left(\eta^{6}-p\right.\right.$-cymene $\left.)\right]$ \\
\hline & $8,953.7$ & $\mathrm{Ub}-\left[\mathrm{Ru}\left(\eta^{6}-p\right.\right.$-cymene $\left.)(\mathrm{pta})\right]$ \\
\hline & $12,592.3$ & Cyt $c-\left[\operatorname{Ru}\left(\eta^{6}-p\right.\right.$-cymene $\left.)\right]$ \\
\hline & $12,749.4$ & Cyt $c-\left[\operatorname{Ru}\left(\eta^{6}-p\right.\right.$-cymene $\left.)(\mathrm{pta})\right]$ \\
\hline \multirow[t]{7}{*}{12} & $8,797.7$ & $\mathrm{Ub}-\left[\mathrm{Ru}\left(\eta^{6}-p\right.\right.$-cymene $\left.)\right]$ \\
\hline & $8,953.7$ & $\mathrm{Ub}-\left[\mathrm{Ru}\left(\eta^{6}-p\right.\right.$-cymene $\left.)(\mathrm{pta})\right]$ \\
\hline & $9,187.7$ & $\begin{array}{l}\mathrm{Ub}-\left[\mathrm{Ru}\left(\eta^{6}-p \text {-cymene }\right)(\mathrm{pta})\right] \\
\quad+\mathrm{Ub}-\left[\mathrm{Ru}\left(\eta^{6}-p \text {-cymene }\right)\right]\end{array}$ \\
\hline & $9,223.7$ & $\begin{array}{l}\mathrm{Ub}-\left[\mathrm{Ru}\left(\eta^{6}-p \text {-cymene }\right)(\mathrm{pta}) \mathrm{Cl}\right] \\
\quad+\mathrm{Ub}-\left[\mathrm{Ru}\left(\eta^{6}-p \text {-cymene }\right)\right]\end{array}$ \\
\hline & $12,592.3$ & Cyt $c-\left[\operatorname{Ru}\left(\eta^{6}-p\right.\right.$-cymene $\left.)\right]$ \\
\hline & $12,749.4$ & Cyt $c-\left[\operatorname{Ru}\left(\eta^{6}-p\right.\right.$-cymene $)($ pta $\left.)\right]$ \\
\hline & $12,983.4$ & $\begin{array}{r}\text { Cyt } c-\left[\operatorname{Ru}\left(\eta^{6}-p \text {-cymene }\right)(\mathrm{pta})\right] \\
+ \text { cyt } c-\left[\operatorname{Ru}\left(\eta^{6}-p \text {-cymene }\right)\right]\end{array}$ \\
\hline
\end{tabular}

residues. The incubation mixture was analysed at different times over a 48 -h period. Selected areas of the ESI MS spectra recorded at different times are reported in Fig. 4. After $24 \mathrm{~h}$, it was possible to identify the signals corresponding to the ubiquitin- $\left[\mathrm{Ru}\left(\eta^{6}-p \text {-cymene }\right)\right]^{2+}$ adduct at approximately $8,797 \mathrm{Da}$ (approximately $30 \%$ relative intensity), while no cisplatin-ubiquitin species were detected (Fig. 4a). The same ruthenium adduct was the only metal-containing species detected after $48 \mathrm{~h}$, and increased in relative intensity to become the predominant species with respect to unbound ubiquitin (Fig. 4a). In the case of cytochrome $c$ and SOD, cytochrome $c-\mathrm{Pt}\left(\mathrm{NH}_{3}\right)_{2} \mathrm{H}_{2} \mathrm{O}$ and SOD-Pt $\left(\mathrm{NH}_{3}\right)_{2}$ adducts were detected at approximately 12,604 $\mathrm{Da}$ (approximately 10\% relative intensity) (Fig. 4b) and approximately $15,818 \mathrm{Da}$ (approximately $10 \%$ relative intensity) (data not shown), respectively. After $48 \mathrm{~h}$, the cytochrome $c-\left[\operatorname{Ru}\left(\eta^{6}-p \text {-cymene }\right)\right]^{2+}$ adduct appears at approximately $12,591 \mathrm{Da}$ (approximately $10 \%$ relative intensity). Remarkably, no ruthenium adducts with SOD were detected.

Overall, these spectra suggest that RAPTA-C competes with cisplatin for the same binding sites on the three selected proteins. In fact, it has been shown that when one of the two complexes forms adducts, the other one is not able to react or at least its binding is highly reduced. With respect to ubiquitin, the most reactive metallodrug is RAPTA-C. Remarkably, in the case of cytochrome $c$, neither complex dominates and the corresponding relative intensities remain in the range $10-20 \%$.
In a further series of experiments, cisplatin was reacted with the three proteins and then an excess of RAPTA-C was added (see "Sample preparation and mass-spectrometric analysis" for full details). This alternative approach was applied to confirm the affinity of the two complexes for the same binding sites, but without disrupting the physiological-like conditions, which is the case when an excess of the two drugs is employed at the same time, as reported above. The spectra obtained are shown in Fig. 5, with Fig. 5a focusing on the region containing peaks for ubiquitin and its adducts. In Fig. 5a, trace a corresponds to the spectrum of a cisplatin-treated sample after 72-h incubation and trace $\mathrm{b}$ corresponds to the same sample after addition of RAPTA-C. Figure $5 b$ shows the analogous regions of the spectrum for the region attributable to cytochrome $c$ adducts.

After $24 \mathrm{~h}$ following addition of RAPTA-C to the protein-cisplatin incubation mixture, apart from platinumprotein adducts, only low-intensity signals corresponding to ruthenium-bound species were detected for both ubiquitin and cytochrome $c$ at 8,796.6, corresponding to ubiquitin-[Ru( $\eta^{6}-p$-cymene $\left.)\right]$, and $12,750.4 \mathrm{Da}$, corresponding to cytochrome $c-\left[\operatorname{Ru}\left(\eta^{6}-p\right.\right.$-cymene $)$ pta $]$. In the case of SOD only cisplatin adducts were detected (data not shown), which is expected since RAPTA-C showed relatively low binding to this protein in the absence of cisplatin. Again, these data suggest that RAPTA-C competes with cisplatin for the same binding sites on the three selected proteins. It is worth noting that all the adducts were assigned on the basis of comparisons between observed and theoretical high-resolution MS spectra, which are in excellent agreement. As an example, Fig. 6 shows the +7 charge state for the ubiquitin- $\mathrm{Pt}\left(\mathrm{NH}_{3}\right)_{2}$ and ubiquitin- $\left[\mathrm{Ru}\left(\eta^{6}-p\right.\right.$-cymene $\left.)\right]$ adducts for a protein mixture treated with excess cisplatin for $72 \mathrm{~h}$ and then reacted with RAPTA-C for an additional $24 \mathrm{~h}$ (at $37^{\circ} \mathrm{C}$ ). Figure S1 shows the theoretical and observed isotope patterns of the cytochrome $c-\left[\operatorname{Ru}\left(\eta^{6}-p\right.\right.$-cymene)(pta) $]$ adduct in the same sample at charge state +9 .

The same type of competition experiment was repeated by treating the mixture of proteins first with RAPTA-C and then with cisplatin. Again, a limited number of platinum adducts were detected for cytochrome $c$ only, confirming that the platinum complex competes with the organometallic ruthenium compound for the same binding sites on the proteins (see Fig. S2). Previous studies on the determination of the protein binding sites of metal complexes employed the MS identification of peptides cleaved by proteases (e.g. trypsin or Asp-N) [32]. In addition, chemical modifications of specific residues on the protein side chain (e.g. Met oxidation) before addition of the metal complex have been used to confirm binding sites. For cisplatin the preferential site on cytochrome $c$ and ubiquitin 
a
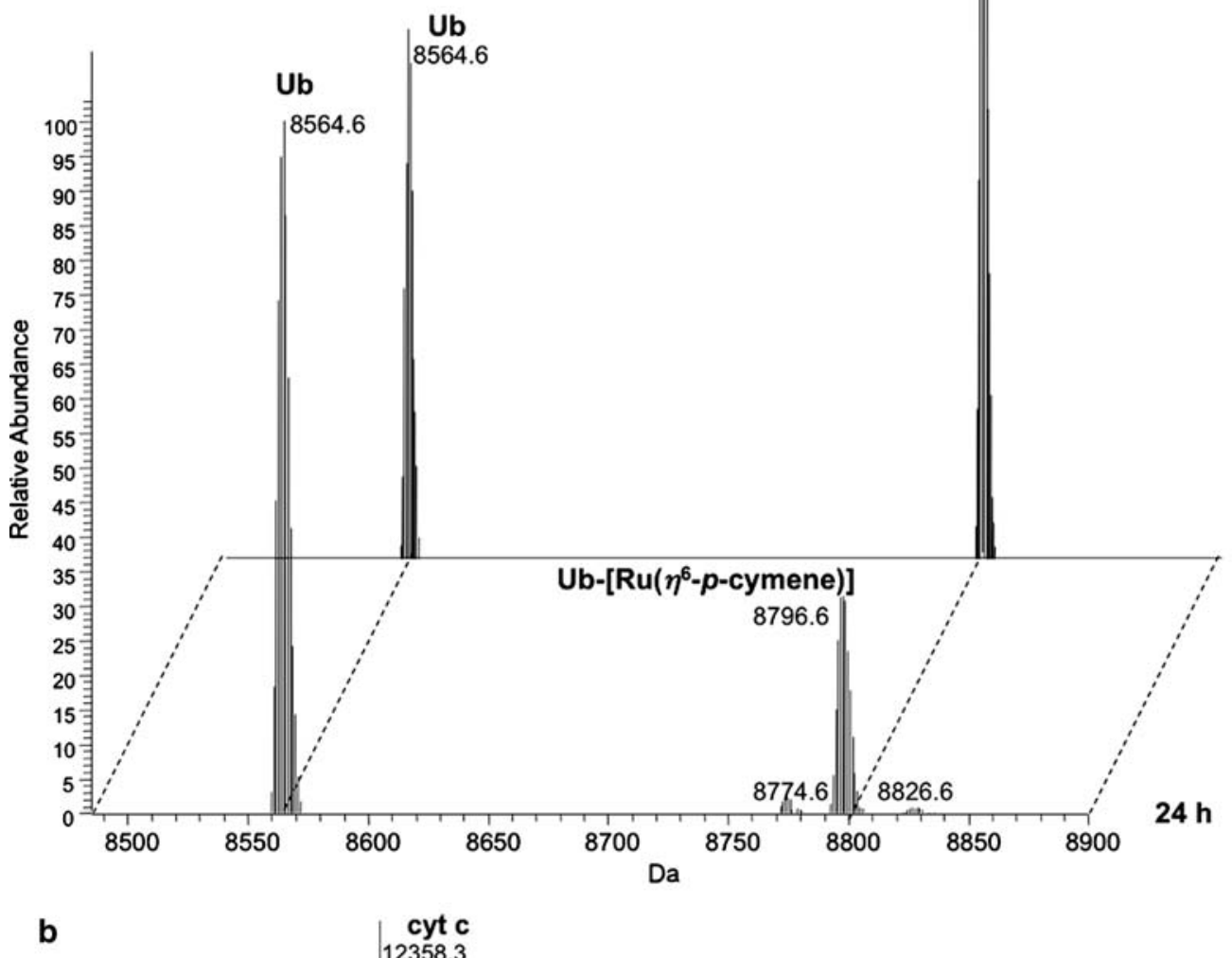

b$$
\text { } 100
$$$$
\begin{aligned}
& 100 \\
& 95 \\
& 90 \\
& 85 \\
& 80 \\
& 75 \\
& 70 \\
& 65 \\
& 60 \\
& 55 \\
& 50 \\
& 45 \\
& 40 \\
& 35 \\
& 30 \\
& 25 \\
& 20 \\
& 15 \\
& 10 \\
& 5 \\
& 0 \\
&
\end{aligned}
$$

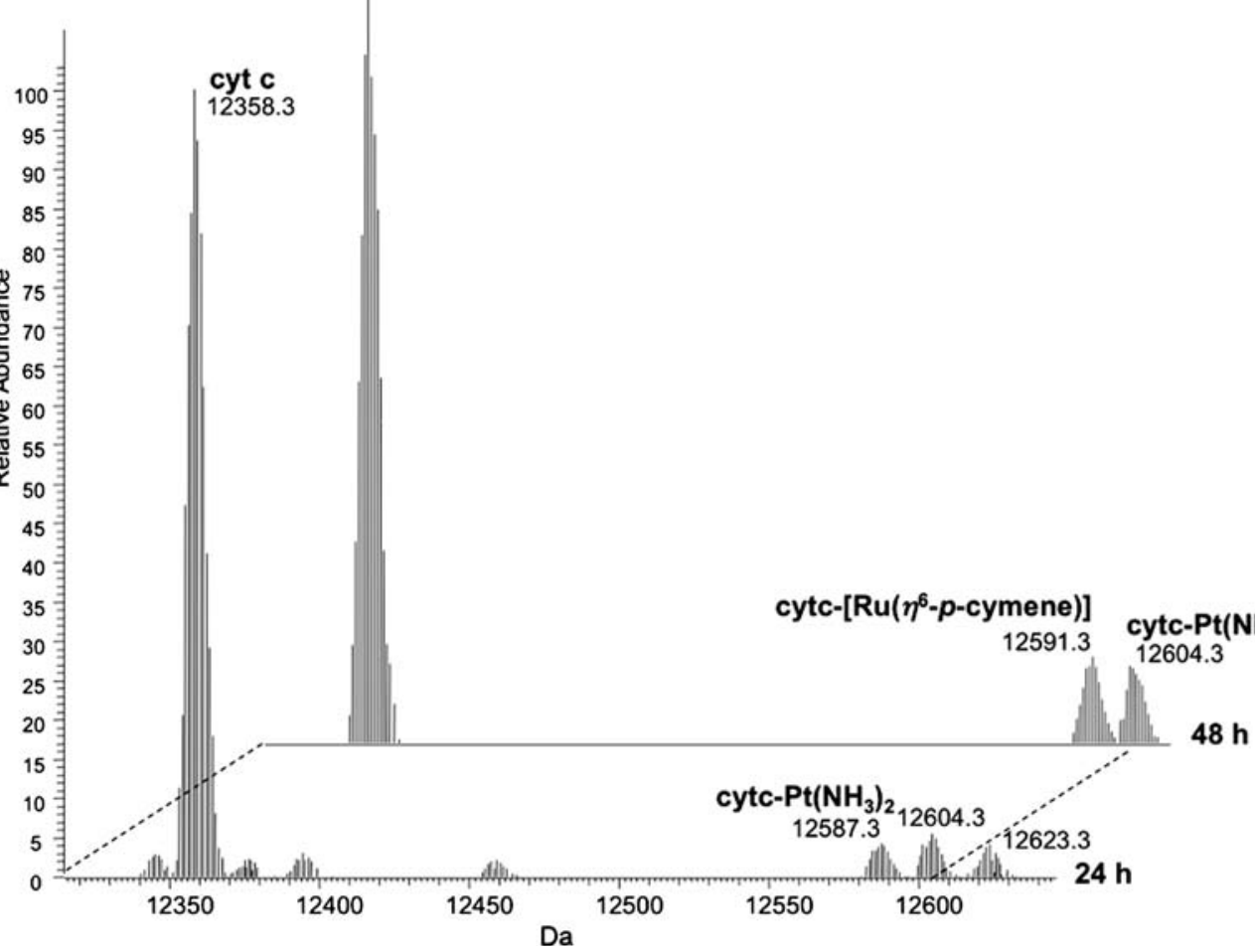

Fig. 4 LTQ-Orbitrap ESI mass spectra of the protein mixture treated with cisplatin and RAPTA-C (5:1 metal-to-protein ratio) in TMeAmAc buffer $\mathrm{pH} 7.4$ after 24 and $48 \mathrm{~h}$. a The region of the spectrum

\section{Ub-[Ru( $\eta^{6}$-p-cymene)]}

8796.6

concerning the Ub adducts. b The region of the spectrum concerning the cyt $c$ adducts 

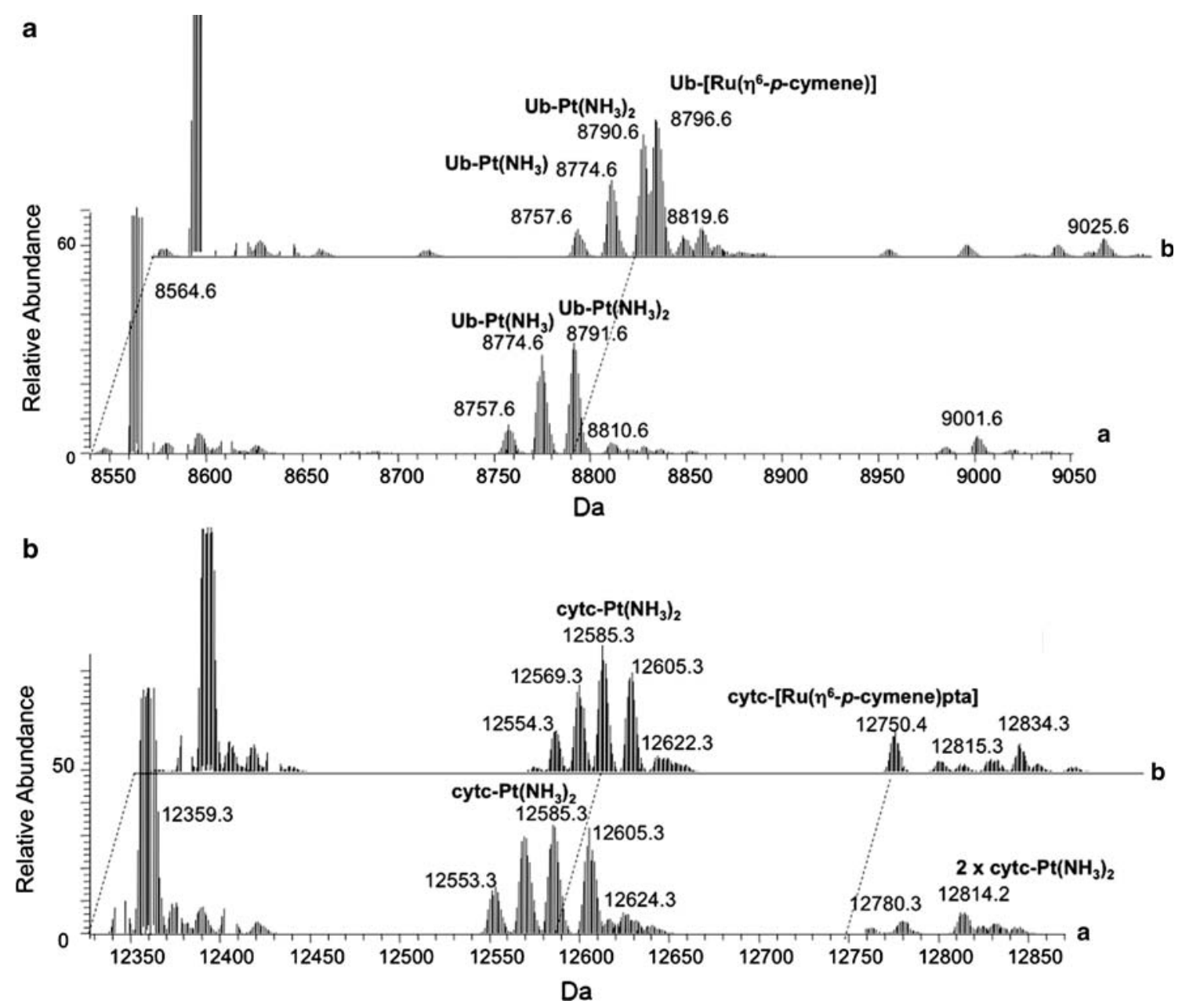

Fig. 5 LTQ-Orbitrap ESI mass spectra of the protein mixture treated with cisplatin (5:1 metal-to-protein ratio) in TMeAmAc buffer $\mathrm{pH} 7.4$ before (trace $a$ ) and $24 \mathrm{~h}$ after addition of RAPTA-C (5:1 metal-to-

appears to be a Met residue, with the His residues being secondary target sites $[21,45]$. Nevertheless, the presence of multiple adducts in the spectra indicates that several residues in the proteins might be involved.

It would appear that the target residues correspond to those that are more exposed on the surface of the protein and therefore easily accessible for metal binding. So, for example, X-ray structural data on cisplatin-treated SOD unambiguously reveal a preference of platinum binding for His compared with Met or Cys residues [46]. This preference may be, at least in part, ascribed to the fact that access to either Met-115 or Cys-6, the only "free" sulphur-containing groups of SOD are somehow sterically hindered; conversely Cys-55 and Cys-144, both solvent-accessible, are engaged in the formation of an internal disulphide bridge and are therefore less prone to react with a metal complex.

Thus far, no definite protein binding sites have been assigned for RAPTA-C, although some His residues have protein ratio) (trace $b$ ). a The region of the spectrum concerning the $\mathrm{Ub}$ adducts. $\mathbf{b}$ The region of the spectrum concerning the cytochrome $c$ adducts

been tentatively proposed for ruthenium compounds [47, 48]. Here, we showed that the primary target amino acids appear to be the same for both cisplatin and RAPTA-C. Since RAPTA-C is the only metal compound to show selective protein binding, it is not unreasonable to attribute this feature to the greater steric demand imposed by RAPTA-C and possible hydrophobic interactions induced by the arene ring, thereby increasing the selectivity of such organometallic compounds relative to simple coordination complexes. The implications of such interactions are likely to be important in future drug design.

\section{Conclusions}

High-resolution MS coupled with a "soft" ionisation method, i.e. ESI MS, provides detailed information on metallodrug-protein interactions that give fundamental insights into their modes of action. In the present study, the 


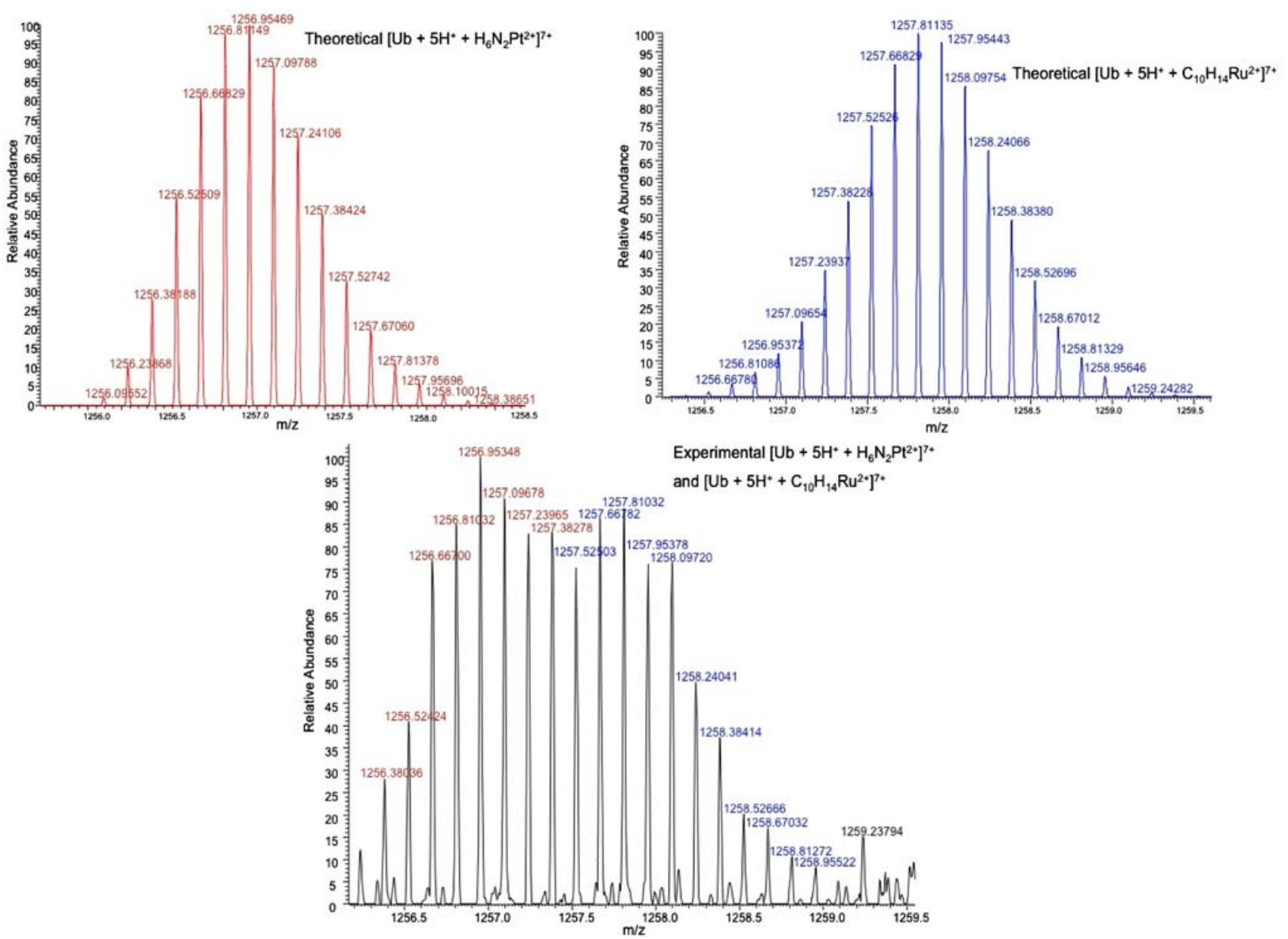

Fig. 6 Theoretical and observed isotope patterns of $\mathrm{Ub}-\mathrm{Pt}\left(\mathrm{NH}_{3}\right)_{2}(r e d)$ and $\mathrm{Ub}-\left[\mathrm{Ru}\left(\eta^{6}-p\right.\right.$-cymene $\left.)\right]($ blue $)$ adducts in charge state +7

reactivity of representative metallodrugs with a mixture of proteins was probed without using any chromatographic separation prior to analysis.

Differences in the selectivity of the various metal complexes were readily identified using this approach. In particular, cisplatin was moderately reactive towards the proteins without any discrimination/selectivity, whereas RAPTA-C was considerably more reactive and could also discriminate between ubiquitin/cytochrome $c$ and SOD. Such information has important implications for the mode of action of the metallodrugs in the cell and presumably also for their toxic side effects. Once actual protein targets have been established, it would be interesting to screen them in the presence of other proteins, as described here, to provide an indication of their selectivity.

Acknowledgment A.C. thanks the Swiss National Science Foundation for financial support (AMBIZIONE project no. PZ00P2_121933).

\section{References}

1. Natile G, Coluccia M (2004) Met Ions Biol Syst 42:209-250

2. Gabbiani C, Casini A, Messori L (2007) Gold Bull 40(1):73-81

3. Hartinger CG, Zorbas-Seifried S, Jakupec MA, Kynast B, Zorbas H, Keppler BK (2006) J. Inorg Biochem 100:891-904

4. Hall MD, Dolman RC, Hambley TW (2004) Met Ions Biol Syst 42:297-322

5. Ang WH, Dyson PJ (2006) Eur J Inorg Chem 20:4003-4018

6. Vessières A, Top S, Beck W, Hillard E, Jaouen G (2006) Dalton Trans 4:529-541

7. Allardyce CS, Dyson PJ, Ellis DJ, Heath SL (2001) Chem Commun 1396-1397

8. Dyson PJ, Sava G (2006) Dalton Trans 1929-1933

9. Scolaro C, Bergamo A, Brescacin L, Delfino R, Cocchietto M, Laurenczy G, Geldbach TJ, Sava G, Dyson PJ (2005) J Med Chem 48:4161-4171

10. Bergamo A, Masi A, Dyson PJ, Sava G (2008) Int J Oncol 33(6):1281-1289

11. Alessio E, Mestroni G, Bergamo A, Sava G (2004) Curr Top Med Chem 4:1525-1535

12. Hartinger CG, Jakupec MA, Zorbas-Seifried S, Groessl M, Egger A, Berger W, Zorbas H, Dyson PJ, Keppler BK (2008) Chem Biodivers 5(10):2140-2155 
13. Lippert B (1999) Cisplatin: chemistry and biochemistry of a leading anticancer drug. Wiley, New York

14. Brabec V (2002) Prog Nucleic Acid Res Mol Biol 71:1-68

15. Pintus G, Tadolini B, Posadino AM, Sanna B, Debidda M, Bennardini F, Sava G, Ventura C (2002) Eur J Biochem 269(23):5861-5870

16. Chatterjee S, Kundu S, Bhattacharyya A, Hartinger CG, Dyson PJ (2008) J Biol Inorg Chem 13(7):1149-1155

17. Gaiddon C, Jeannequin P, Bischoff $P$, Pfeffer $M$, Sirlin C, Loeffler JP (2005) J Pharmacol Exp Ther 315(3):1403-1411

18. Reedijk J (2003) Proc Natl Acad Sci USA 100:3611-3616

19. Knipp M, Karotki AV, Chesnov S, Natile G, Sadler PJ, Brabec V, Vasák M (2007) J Med Chem 50(17):4075-4086

20. Casini A, Gabbiani C, Sorrentino F, Rigobello MP, Bindoli A, Geldbach TJ, Marrone A, Re N, Hartinger CG, Dyson PJ, Messori L (2008) J Med Chem 51(21):6773-6781

21. Hartinger CG, Tsybin YO, Fuchser J, Dyson PJ (2008) Inorg Chem 47(1):17-19

22. Timerbaev AR, Hartinger CG, Aleksenko SS, Keppler BK (2006) Chem Rev 106:2224-2248

23. Casini A, Guerri A, Gabbiani C, Messori L (2008) J Inorg Biochem 102(5-6):995-1006

24. Casini A, Hartinger C, Gabbiani C, Mini E, Dyson PJ, Keppler BK, Messori L (2008) J Inorg Biochem 102(3):564-575

25. Khalaila I, Allardyce CS, Verma C, Dyson PJ (2005) Chembiochem 6:1788-1795

26. Peleg-Shulman T, Najajreh Y, Gibson D (2002) J Inorg Biochem 91(1):306-311

27. Cristoni S, Bernardi LR (2003) Mass Spectrom Rev 22(6): 369-406

28. Di Marco VB, Bombi GG (2006) Mass Spectrom Rev 25(3): 347-379

29. Karotki AV, Vasák M (2008) Biochemistry 47(41):10961-10969

30. Casini A, Gabbiani C, Mastrobuoni G, Messori L, Moneti G, Pieraccini G (2006) ChemMedChem 1(4):413-417

31. Hartinger CG, Ang WH, Casini A, Messori L, Keppler BK, Dyson PJ (2007) J Anal At Spectrom 22:960-967

32. Casini A, Gabbiani C, Mastrobuoni G, Pellicani RZ, Intini FP, Arnesano F, Natile G, Moneti G, Francese S, Messori L (2007) Biochemistry 46(43):12220-12230
33. Jiang X, Wang X (2004) Annu Rev Biochem 73:87-106

34. Pickarta CM, Eddins MJ (2004) Biochim Biophys Acta 1695: 55-72

35. Noor R, Mittal S, Iqbal J (2002) Med Sci Monit 8(9):RA210RA215

36. Hu Q, Noll RJ, Li H, Makarov A, Hardman M, Graham Cooks R (2005) J Mass Spectrom 40:430-443

37. Casini A, Mastrobuoni G, Temperini C, Gabbiani C, Francese S, Moneti G, Supuran CT, Scozzafava A, Messori L (2006) Chem Commun 156-158

38. Hartinger CG, Casini A, Duhot C, Tsybin YO, Messori L, Dyson PJ (2008) J Inorg Biochem 102(12):2136-2141

39. Breitling R, Pitt AR, Barrett MP (2006) Trends Biotechnol 24(12):543-548

40. Madalinski G, Godat E, Alves S, Lesage D, Genin E, Levi P, Labarre J, Tabet JC, Ezan E, Junot C (2008) Anal Chem 80(9):3291-3303

41. Erve JC, Demaio W, Talaat RE (2008) Rapid Commun Mass Spectrom 22(19):3015-3026

42. Hofstadler SA, Sannes-Lowery KA (2006) Nat Rev Drug Discov 5(7):585-595

43. Will J, Kyas A, Sheldrick WS, Wolters DA (2007) J Biol Inorg Chem 12:883-894

44. Will J, Sheldrick WS, Wolters D (2008) J Biol Inorg Chem 13(3):421-434

45. Gabbiani C, Casini A, Mastrobuoni G, Kirshenbaum N, Moshel O, Pieraccini G, Moneti G, Messori L, Gibson D (2008) J Biol Inorg Chem 13:755-764

46. Calderone V, Casini A, Mangani S, Messori L, Orioli PL (2006) Angew Chem Int Ed 45(8):1267-1269

47. Casini A, Mastrobuoni G, Ang WH, Gabbiani C, Pieraccini G, Moneti G, Dyson PJ, Messori L (2007) ChemMedChem 2(5):631-635

48. Casini A, Mastrobuoni G, Terenghi M, Gabbiani C, Monzani E, Moneti G, Casella L, Messori L (2007) J Biol Inorg Chem 12(8):1107-1117 